\title{
EFFECT OF COMPETENCE OF THE AUDIT COMMITTEE AND AUDITORS OF THE BIG FIVE PUBLIC ACCOUNTING FIRM ON TAX AVOIDANCE
}

\author{
Indayani Lis \\ Faculty of Economics and Business, University of Airlangga, Indonesia \\ E-mail: lisindayani048@gmail.com
}

\begin{abstract}
Research this aiming for knowing the influence of the competence of the audit committee and auditor of the Big 5 Public Accountants Office on tax avoidance. Research conducted using a quantitative approach with data analysis using multiple linear regression. The research sample used by manufacturing companies listed on the Indonesia Stock Exchange in 2013-2017. Results research shows that the competence of the audit committee has no effect on corporate tax avoidance. Similarly, the auditors of the Big 5 Public Accounting Firm also have no influence on corporate tax avoidance.
\end{abstract}

\section{KEY WORDS}

Taxation, competence, audit, committee, auditor.

Indonesia was ranked the 11th largest in terms of corporate tax avoidance with a value estimated at 6.48 billion US dollars. This is based on a report made by Ernesto Crivelly and investigators from the IMF in 2016. The report was based on a survey which was then reanalyzed by the United Nations University using a database of the International Center for Policy and Policy (ICPR) and the International Center for Taxation and Development (ICTD) then 30 state tax avoidance data appeared (www.tribunnews.com).

In a company, to determine the amount of tax to be paid to the state treasury is influenced by many factors. Among them is corporate governance or generally called corporate governance, is a mechanism that regulates and controls a company through relationships between other internal and external stakeholders so as to increase the value of the company (Darmawan and Sukartha, 2014). In its own corporate governance, supervision is the most important part so that the company can run well. In order for supervision to be effective and efficient, the company forms an audit committee.

According to Robinson, Xue, and Zhang (2012) the audit committee's accounting or financial expertise is positively related to low risk tax avoidance and is negatively related to high risk tax avoidance. The same thing was also revealed by Hsu, Moore and Neubaum (2018) that audit committees that are independent and have financial expertise are negatively related to corporate tax avoidance. But it is different from Puspita and Harto (2014), found that the audit committee's accounting or financial expertise background did not influence tax avoidance. This finding is the same as that expressed by Mahidi and Danastri (2015) and Wijayanti et al (2016).

In addition to internal supervision, supervision is also carried out from external companies. Supervision from external companies can be done by KAP in the big 5 category. McGuire, Omer, and Wang (2012) say that the expertise of external auditors influences corporate tax avoidance. $\mathrm{H}$ al Similar dikemukan Taylor and Richardson (2013) that the big four auditors negatively affect the company's tax evasion. But this is different from the findings of Hartadinata and Tjaraka (2013) who say that audit quality has no effect on tax avoidance.

\section{THEORETICAL REVIEW}

Agency relationship occurs when one or more people, called principals, employ other individuals or organizations, called agents to carry out a number of services and delegate authority to make decisions to the agent. According to Eisenhardt (1989), agency theory has 
three assumption of human nature, namely: general human selfishness (self-interest), humans have the power of thought is limited regarding the perception future (bounded rationaliy), and human beings always avoid the risk (risk averse). Thirdly it causes management to take action to tax evasion, but the legal way by exploiting loopholes of tax laws that exist.

Fritz Heider developed an attribution theory which states that "a person's behavior is determined by two combinations of internal and external forces. Internal strength is a factor that comes from within the person himself while external forces are factors that come from outside" (Suartana, 2010). Whereas Robbins (2008) concluded that "behavior caused internally is a behavior believed to be influenced by an individual's personal control. Behavior caused externally is considered as the consequences of external causes, the individual is considered to have been forced to behave accordingly by the situation ".

Behavior caused externally is considered as a result of external causes, where management is considered to have been forced to carry out tax avoidance activities. External factors here, for example, are the encouragement of shareholders to maximize profits, so management is forced to take advantage of tax regulations so that the tax burden is relatively small, because basically no company voluntarily willing to pay taxes.

Tax evasion or tax avoidance is one part of the tax management. Tax management is a way to fulfill tax obligations but by reducing the amount of tax paid to be as small as possible to obtain the desired profit and liquidity (Suandy, 2011: 6). There are three functions of tax management, namely: tax planning tax implementation and tax control.

According to Brown (2012: 1), tax avoidance is a " arrangement of a tax advantage, benefit or reduction in manner is unintended by the tax law ". That is, regulating transactions to get tax benefits, benefits or deductions in a way that is not desired by law per tax.

From the definition above it can be concluded that tax avoidance is an effort made by taxpayers to minimize payment of their tax due to the loopholes contained in the tax law. Businesses carried out can be said not to violate the law because they are still within the corridor of tax law.

The audit committee is part of corporate governance that was formed with the aim of assisting the board of commissioners in supervising the company's performance. Audit Committee responsible and responsible for providing professional and independent opinions to the board of commissioners on reports or matters submitted by the board of commissioners, and carrying out other tasks related to the duties of the board of commissioners.

The number of audit committee members consists of at least 3 (three) people from independent commissioners and parties outside the company. Audit committee members must have 1 (one) member who has an accounting education background or has expertise in finance (the Financial Services Authority, 2015). Accounting education background or expertise in finance is related to the competencies that must be possessed by audit committee members.

Big $5 \mathrm{KAP}$ auditors are related to auditor quality. KAP that is included in the ranks of the big 5 certainly has no doubt quality. The quality of auditors also supports the application of the principles of good corporate governance, namely transparency and accountability. This is expected to help management not to avoid unwanted tax evasion.

According to De Angelo (1981) audit quality can be seen from the size of the KAP that conducted the audit, which is believed that KAP included in the Big 5 rank has good quality and reputation because of the large amount of training provided to its employees. Big $5 \mathrm{KAP}$ auditors are more competent and professional than non big 5 auditors so companies that use big 5 KAP services will tend to be smaller in cheating. The competencies possessed by big 5 KAP will help make it easier to detect if there is fraud or data manipulation so that the quality of financial statements audited by KAP big 5 is much better than those audited by non-big 5 . This certainly will also make it difficult for management to avoid tax evasion unwanted.

Research Robinson et al., (2012) showed that the company's audit committee that has the accounting skills associated with the level of tax evasion. Audit committee accounting expertise is positively related to low risk tax avoidance and negatively related to high risk tax 
avoidance. McGuire et al., (2012) found that the expertise of external auditors in the field of taxes had an effect on corporate tax avoidance.

Then there was research from Taylor and Richardson (2013), research shows that corporate governance is related to the independence of the board of directors, the level of constitutional ownership, the use of big 4 external auditors negative effect related to corporate tax avoidance. In 2015 research from Armstrong, Blouin, and Jagolinzer (2015), corporate governance is specifically examined using two supporting variables from the board, namely financial expertise (knowledge of costs and benefits of tax avoidance) and independence (ability and incentives to monitor tax avoidance decisions made by managers). The latest research was conducted by Hsu et al., (2018) that shows that an independent audit committee members with expertise finance related negative with tax evasion.

The results of the study from Robinson et al. (2012) found a positive influence of the competence of the audit committee on low-risk tax avoidance. Then Armstrong et al., (2015) said that the board of directors who are independent and have knowledge in the financial field have an influence on corporate tax avoidance. Hsu et al., (2018) also found that the audit committee is independent and has financial expertise related to corporate tax avoidance. $\mathrm{M}$ aka the hypothesis put forward by the researchers:

$\mathrm{H}_{1}$ : Competence of the audit committee has a positive effect on corporate tax avoidance.

Research conducted by McGuire et al. (2012) found that the expertise of external auditors plays an important role in corporate tax avoidance. Furthermore, Taylor and Richardson (2013) with the findings of the use of big 4 external auditors have a negative effect on corporate tax avoidance. So the researcher makes a hypothesis: avoidance.

$\mathrm{H}_{2}$ : The use of big 5 external auditor services has a negative effect on corporate tax

\section{METHODS OF RESEARCH}

Quantitative research approach using descriptive analysis method was chosen in this study. In this study there are three research variables, namely tax avoidance $(Y)$ as the dependent variable and the independent variable consists of the competence of the audit committee $\left(\mathrm{X}_{1}\right)$ and the big external auditor $5\left(\mathrm{X}_{2}\right)$.

The competence of the audit committee is calculated by comparing the number of members who have an accounting education background or experience in finance with the total number of members of the audit committee as a whole. Like research conducted by Puspita and Harto (2014).

Then for the big 5 external auditor variables seen from the auditors who audited the financial statements came from KAP which entered the top five best KAP.

Population and Samples

The research sample used is a manufacturing industry company listed on the Indonesia Stock Exchange. The sampling method that will be used is non-probabilistic sampling, more specifically the purposive sampling method because this study has certain sample criteria that are tailored to the research objectives.

This research is quantitative by using secondary data in the form of financial reports and related research documents. The data used in this study was obtained from the IDX website (www.idx.co.id).

Hypothesis testing is done by using a multiple linear regression analysis model which aims to predict the effect of independent variables on the dependent variable (Ghozali, 2011: 82). The results of data processing will be presented in tables and descriptive. The regression equation is:

$$
\mathrm{Y}=\mathrm{b}_{0}+\mathrm{b}_{1} \mathrm{X}_{1}+\mathrm{b}_{2} \mathrm{X}_{2}+e
$$

Where: $\mathrm{Y}=$ Tax Avoidance; $\mathrm{X}_{1}=$ Audit Committee Competence; $\mathrm{X}_{2}=$ External Auditor big 5. 


\section{RESULTS AND DISCUSSION}

In this study, the population used was manufacturing companies listed on the Indonesia Stock Exchange in 2013 - 2017. The company samples that were successfully obtained were 513 companies from 707 manufacturing companies listed on the IDX.

Multiple linear regression analysis is used to test the effect of two or more independent variables on one dependent variable. In this study used the $t$ test and coefficient of determination (Ghozali, 2011: 127). The multiple linear regression equation in this study is formulated by the equation:

$$
Y=b 0+b 1 X 1+b 2 \times 2+e
$$

Table 1 - Multiple Linear Regression Test Results

\begin{tabular}{|l|c|c|c|c|c|}
\hline \multicolumn{2}{|c|}{ Model } & B & T & Sig & Information \\
\hline \multirow{3}{*}{1} & Constant & 0.040 & 4,127 & 0,000 & Not supported \\
\cline { 2 - 6 } & KKA & $-0,022$ & $-1,553$ & 0.121 & Not supported \\
\cline { 2 - 6 } & Big 5 & -0.002 & $-0,263$ & 0.793 & Not supported \\
\hline \multicolumn{2}{l}{ a. Dependent Variable: Tax Avoidance } \\
\hline
\end{tabular}

Source: SPSS Processed Products (2019).

From the table data, we can compile multiple linear regression equations as follows:

$$
Y=0,040-0,022 X_{1}-0,002 X_{2}
$$

Based on the equation of the results of multiple linear regression, the constant value for the regression equation shows 0.040 . That is, when the competence of the audit committee and the big 5 KAP auditors is considered constant, the amount of tax avoidance will increase by 0.040 cases.

Partial hypothesis testing in this study was carried out using the $t$ test. By using the SPSS program and a $5 \%$ significance level the partial test results can be shown in the table.

- The results of the $t$ test for $\mathrm{H}_{1}$ obtained $t$ count -1.553 with a significance value of more than 0.05 , which is 0.121 and has a negative coefficient direction of -0.022 . Negative values indicate the opposite direction of the dependent variable and a greater significance value means that the independent variable has no influence on the dependent variable. So $H_{1}$ is rejected because the $t$ test shows a negative direction and has no influence;

- The results of the $t$ test for $\mathrm{H}_{2}$ obtained the value of $t$ count -0.263 with a significance value of more than 0.05 , which is 0.793 and has a negative coefficient direction of 0.002 . Negative values indicate the opposite direction of the dependent variable and a greater significance value means that the independent variable has no influence on the dependent variable. So $\mathrm{H}_{2}$ is also rejected because the thest shows that the independent variable has no influence on the dependent variable even though it has a negative direction.

The test results of the coefficient of determination indicate that the value is adjusted $\mathrm{R}^{2}$ amounting to 0.001 . This number indicates that it is $0.1 \%$ variation the dependent variable (tax avoidance) which can be explained by variation of independent variables (competence of the audit committee and auditor KAP $b$ ig 5) in this study. This indicates the ability of the independent variable is not strong in explaining the dependent variable.

The results of the testing of the first hypothesis indicate that the audit committee competency variable which is defined as KKA has a p-value of 0.121 that has no effect on tax avoidance. $\mathrm{H}$ al may also be due in carrying out its duties and responsibilities, the audit committee restricted their authority, such as cannot access the documents, data or information about the company and the difficulty berkomun IKASI with employees including $d$ 
ireksi and others who carry out the audit function internal and audit committee also does not have the authority to make decisions. P establishes an audit committee of a company only to comply with applicable regulations. So with such conditions, the competence of the audit committee in processing data for tax purposes has no effect on tax avoidance.

The results of the study which said that the competence of the audit committee had no influence on tax avoidance had also been raised by Puspita and Harto (2014), then Mahidin and Danastri (2015). Thus the first hypothesis which states that the audit committee competency has a positive effect on corporate tax avoidance is not proven.

Results of testing the second hypothesis indicates that the variable auditor KAP big $5 \mathrm{~d}$ iprosikan big 5 have a p-value of 0.793 has no influence on tax evasion, because there penin gkatan audit quality at KAP non big 5 as the implications of increasingly strict regulations issued by Bapepam and Financial Institutions concerning Registration of Accountants Who Conduct Activities in the Capital Market (Kep-41/BL/2008). Then the regulations issued by Bapepam and Financial Institutions were issued No. Kep 431/BL/2012 concerning Submission of Annual Report of Issuers or Public Companies. This regulation is issued considering the Public Company Annual Report is an important source of information about performance and prospects companies for shareholders and the public for investment decision making, and in order to improve the quality of information disclosure in the annual reports of public companies, so that it can indirectly improve audit quality.

Research conducted by Hartadinata and Tjaraka (2013) said that audit quality had no effect on tax avoidance. This is in accordance with the results of the study which shows that the big $5 \mathrm{KAP}$ auditors have no effect on tax avoidance. So that the second hypothesis which says that the big 5 KAP auditors have a negative effect on tax avoidance is not proven.

\section{CONCLUSION}

The results of the study indicate that the audit committee's competency variable has no effect on tax avoidance. This may be because in carrying out their duties and responsibilities, the audit committee is limited by its authority, such as not being able to access company documents, data or information and the difficulty of communicating with employees including directors and other parties who carry out internal audit functions as well as the audit committee.

Then for the results of the research the big $5 \mathrm{KAP}$ auditor variables on tax avoidance also showed no influence. This may be a result of the increasingly stringent regulations issued by Bapepam and Financial Institutions concerning Registration of Accountants which Conduct Activities in the Capital Market (Kep-41/BL/2008). Then the regulations issued by Bapepam and Financial Institutions were issued Kep 431/BL/2012 concerning Submission of Annual Report of Issuers or Public Companies.

The results of the coefficient test $\left(R^{2}\right)$ itself indicate that the value is adjusted $R^{2}$ amounting to 0.001 . This means that variations in tax avoidance variables that can be explained by variations in the audit committee's competency variables and KAP auditors big 5 are only $0.1 \%$.

\section{REFERENCES}

1. Armstrong, C.S., Blouin, J.L., \& Jagolinzer, A. D. (2015). Corporate Governance, Incentives, and Tax Avoidance. Journal of Accounting and Economis.

2. Brown, K. B. (2012). A Comparative Look at Regulation of Corporate Tax Avoidance. New York: Springer.

3. Darmawan, I. G. H., \& Sukartha, I. M. (2014). Pengaruh Penerapan Corporate Governance, Leverage, Return on Assets, and Ukuran Perusahaan Pada Penghindaran Pajak. Jurnal Bisnis Manajemen and Ekonomi.

4. DeAngelo, L. E. (1981). Auditor Size and Audit Quality. Journal of Accounting Economics, Vol 3: 183-199. 
5. Eisenhardt, K. (1989). Agency Theory: An Assesment and Review. Academy of Management Review, Vol 14: 41-53.

6. Ghozali, I. (2011). Aplikasi Analisis Multivariate Dengan Program SPSS. Semarang: Badan Penerbit Universitas Diponegoro.

7. Hartadinata, O., \& Tjaraka, H. (2013). Analisis Pengaruh Kepemilikan Manajerial, Kebijakan Hutang, and Ukuran Perusahaan terhadap Tax Aggressiveness pada Perusahaan Manufaktur di Bursa Efek Indonesia Periode Tahun 2008 - 2010. Jurnal Ekonomi and Bisnis, XXIII (3): 48-59.

8. Hsu, P.H. (2018). Tax Avoidance, Financial Experts on The Audit Committee, and Business Strategy. Journal of Business Finance and Accounting.

9. Mahidin, I., \& Danastri, N. D. (2015). Analisis Komisaris Independen, Komite Audit, Kepemilikan Keluarga, and Ukuran Perusahaan Terhadap Penghindaran Pajak (Tax Avoidance). Journal of International Accounting, Auditing and Taxation.

10. McGuire, S. T., Omer, T. C., \& Wang, D. (2012). Tax planning: Does Tax-Specific Industry Expertise Make a Difference? The Accounting Review, Vol 87 No. 3: 975-1003.

11. Otoritas Jasa Keuangan (2015). Peraturan Otoritas Jasa Keuangan No. 55 Tahun 2015.

12. Pohan, C. A. (2016). Manajemen Perpajakan Strategi Perencanaan Pajak and Bisnis. Jakarta: PT. Gramedia.

13. Puspita, S.R. (2014). Pengaruh Tata kelola Perusahaan Terhadap Penghindaran Pajak. Diponegoro Journal of Accounting.

14. Robbins, S. P., \& Judge. (2008). Perilaku Organisasi, Buku 2. Jakarta: Salemba Empat.

15. Robinson, J. R. (2012). Tax Planning and Financial Expertise in The Audit Committee.

16. Suandy, E. (2011). Hukum Pajak, Edisi 5. Jakarta: Salemba Empat.

17. Suartana, I. (2010). Akuntansi Keperilakuan Teori and Implementasi. Penerbit Andi.

18. Taylor, G., \& Richardson, G. (2013). The Determinants of Thinly Capitalized Tax Avoidance Structures: Evidence from Australian Firms. Journal of International Accounting, Auditing and taxation.

19. Wijayanti, A. (2016). Pengaruh Karakteristik Perusahaan, Gcg and Csr Terhadap Penghindaran Pajak. Seminar Nasional IENACO 2016.

20. Windarti, A. (2017). Book Tax Difference and Struktur Kepemilikan Sebagai Upaya penghindaran Pajak. Journal of Applied Business and Economics, Vol 4 No. 1: 1-16. 